\title{
Dual Language Programme: The Perceptions and Challenges of Teachers and Students in Klang, Selangor
}

\author{
Edwin Moses $^{1} \&$ Indira Malani ${ }^{2}$ \\ ${ }^{1}$ Universiti Malaysia Sabah, Kota Kinabalu, Sabah, Malaysia \\ ${ }^{2}$ Universiti Tunku Abdul Rahman, Kampar, Perak, Malaysia \\ *email : edwinmoses24@gmail.com
}

DOI: https://doi.org/10.37134/jpsmm.vol9.1.5.2019

\begin{abstract}
The Dual Language Programme (DLP) was introduced to improve English proficiency among students. It became a hot topic after the Ministry of Education Malaysia (MOE) was asked to review the implementation of DLP as teachers and students face challenges in teaching and learning Science and Mathematics in English. Thus, this study was carried out to identify the views of teachers and students about DLP as well as the challenges they face after its implementation. A total of 146 DLP students consisting of Form 1 and Form 2 students as well as 8 teachers from four secondary schools in Klang, Selangor, participated in this study. Data were obtained through questionnaires. In addition, semi-structured interviews were also conducted among teachers. The findings of the study indicate most teachers and students have favourable views toward DLP implementation, although they face some challenges. Moreover, students are interested in learning Science and Mathematics in English even though their English proficiency is still at an unsatisfactory level.
\end{abstract}

Keywords: Dual Language Programme; Education; Teachers; Students; Perceptions; Challenges

\section{INTRODUCTION}

The Dual Language Programme (DLP) was introduced in 2016 under the Upholding Bahasa Malaysia and Strengthening English Language (MBMMBI) policy after the abolishment of the Teaching and Learning of Science and Mathematics in English (PPSMI) policy by the Malaysian Cabinet in the year 2012. DLP is an English reinforcement program based on school choice. Students are given the option to choose either English or Malay for the teaching and learning of Science, Mathematics, Information Technology and Communication, and Design and Technology subjects (Official Portal for Ministry of Education Malaysia, 2015). The main purpose of DLP is to have more students proficient in English. As the second most important language in Malaysia, English plays a major factor in teaching and learning to acquire knowledge in science, technology as well as other academic fields (Melor, Nur Ainil \& Mohammed Amin, 2013).

Nevertheless, many feedbacks and criticisms from various perspectives arose against this programme. Individuals and non-governmental organisations (NGOs) expressed their dissatisfaction with the government over the implementation of the DLP. Some claim that DLP resembles the policy of Teaching and Learning of Science and Mathematics in English (PPSMI). Datuk Mohd Khairuddin Aman Razali, Member of Parliament for Kuala Nerus, stated that the DLP program is similar to the policy of Teaching and Learning of Science and Mathematics in English, which proved unsuccessful due to student's poor examination performance in 2007 (Malay Mail, 6 February 2019). 
In addition, NGOs have urged the government to reject DLP and prioritise mother tongue education (Free Malaysia Today, 11 April 2019). The United Chinese School Committees' Association (Dong Zong) has opposed the implementation of DLP to protect the characteristics of Chinese primary schools (The Sun Daily, 5 October 2016). They believe that the mother tongue in education plays an essential role in the development of the country. A person with a strong foundation in their mother tongue can master the curriculum well (Carolyn, n.d.). Furthermore, the public believes that using English to teach Science and Mathematics to improve students' English language skills is wrong and ineffective, as can be seen during the implementation of PPSMI.

Professor Datuk Ir. Dr Wan Ramli Wan Daud from Universiti Kebangsaan Malaysia (UKM) disagreed with the stance of using English as the medium of instruction for teaching Science and Mathematics to master English. According to him, many developed countries do not use English as the medium of instruction (Sinar Harian, 12 March 2019). The ministry is still being asked to abolish the Dual Language Programme since its implementation in 2016. The question raised by the researcher: Does DLP have a negative impact on the national education system? Why do DLP teachers face challenges in schools? Has DLP failed to improve students' English proficiency? The students' weaknesses in English cannot be overcome by teaching these subjects in English?

While others criticised the teaching and learning of Science and Mathematics in English, a teacher from Klang had a different opinion. She saw it as a wise decision taken by the ministry to implement the teaching and learning of Science and Mathematics in English (The Star, 5 January 2018). The secretary-general of the National Union of Teaching Profession (NUTP), Harry Tan Huat Hock, advised the Ministry of Education to provide more intensive training to DLP teachers to improve their English proficiency (New Straits Times, 10 March 2019). About 90\% of teachers were not prepared to teach Science and Mathematics in English due to their poor command of English (Nair, 2019). According to Harry Tan, this was also to ensure that the number of teachers is sufficient to teach these subjects in English as the number of teachers is limited throughout the country.

In order to achieve the government's aspiration to make Malaysia a developed nation, Malaysians first must be proficient in English. Therefore, Malaysians have no choice but to start learning Science and Mathematics in English because it is the basis to compete in the international arena. All in all, the implementation of DLP allows students to improve their English proficiency skills and explore a variety of knowledge (Ashairi, Mohamed Yusoff \& Melor, 2017).

\section{OBJECTIVES}

The objectives of this study were to:

1) Identify the perceptions of teachers and students in Klang on the implementation of the Dual Language Programme.

2) Find out the challenges faced by teachers and students in Klang during teaching and learning sessions after the implementation of the Dual Language Programme.

\section{LITERATURE REVIEW}

Several scholars have conducted studies on the Dual Language Programme. Jesica and Hamidah (2017) conducted a study to discover the challenges faced by teachers during the implementation of DLP. Studies show that teachers find teaching students challenging because of poor English proficiency. In addition, teachers were not prepared to conduct teaching due to a lack of guidance and information about DLP. 
Besides, the teachers involved in the programme do not receive specific guidance such as seminars from the ministry to carry out teaching effectively.

A study conducted by Melor and Saiful (2017) to find out the perceptions of preschool teachers in teaching and learning Science and Mathematics in English showed that 58\% of preschool teachers do not agree to teach Science and Mathematics in English. Meanwhile, 74\% of preschool teachers claimed it was difficult to teach these subjects in English. Based on the study, most preschool teachers have an unfavourable perception of PPSMI. They agreed that DLP is the right platform compared to PPSMI as Science and Mathematics can be taught in Malay and English.

Nurfaradilla, Sarah \& Sharifah (2018), in their research, found that teaching Science in English helps students further their studies in related fields and also improves their career prospects. They found that Science teachers supported the ministry's idea to implement DLP in schools. They want to develop their English proficiency to conduct their teaching effectively. In addition, it was discovered that learning Science through DLP enhances students' understanding of the subject, enabling them to familiarise themselves with scientific terms and the English language.

While the study conducted by Norhisham, Norazilawati \& Noraini (2018) showed that the readiness of Science teachers towards the implementation of DLP in terms of knowledge is at a high level, while their competence is at a moderate level. Moreover, Science teachers' interest in the implementation of DLP is at an intermediate level. Their study found that the level of readiness and competence of a teacher will have the most significant impact on students' achievements.

Next, Ashairi, Mohamed Yusoff and Melor (2017) conducted a study to determine the readiness and confidence level among Form One and Form Two students who enrol in the Dual Language Programme. The findings of this study indicate that students' level of readiness and confidence is still at a moderate level. Students doubt their own ability whether they will be able to learn in English. Although students face some challenges in mastering English, they understand the importance of learning in English.

Parental involvement is a must because it is one of the factors that make a program successful (Izquierdo, 2017). Thus, a study conducted by Nadiah \& Melor (2018) stated that most parents accept the implementation of DLP as it develops English language skills among students. Parental support and their level of satisfaction showed positive. So, they decided to enrol their children in schools that practise DLP. Parental involvement positively influences their children's success, and of course, it drives them to better success (Izquierdo, 2017).

\section{METHODOLOGY}

This study is qualitative and quantitative-based research. Two research instruments, such as questionnaires and interviews, were used to achieve the objectives of this study. The set of questionnaires was adapted from the studies of Melor and Saiful (2017) and Jesica and Hamidah (2017). A total of 146 Form One and Form Two students, as well as 8 teachers from secondary schools located in Klang, participated in this research survey. Students were randomly selected from each school. The selected schools were SMK Tinggi Klang, SMK Meru, SMK Tengku Ampuan Rahimah and SMK Taman Klang Utama. The questionnaire contained Part A, Part B, and Part C. Part A covered demographic background. Part $\mathrm{B}$ was to get their views on DLP implementation, and Part $\mathrm{C}$ was to find out the challenges they faced during the teaching and learning sessions. Part B and Part C contain open-ended and close-ended questions.

The collected data were analysed using frequency and percentage. The pilot study was conducted before the actual study, in which 32 respondents were randomly selected to test the questionnaires to examine the suitability of the research instrument. Several improvements were made to the question after the pilot study was conducted. Besides, semi-structured interviews were carried out among teachers. It was to have a better understanding of the teachers' perceptions, where some teachers have been exposed 
to PPSMI policy before, which will make it easier for them to compare PPSMI and DLP. 8 interviews were conducted face-to-face, recorded and transcribed. Data were analysed through content analysis and categorised into themes.

\section{FINDINGS}

This study was conducted to answer the research questions: 1) What are the perceptions of teachers and students in Klang on the implementation of the Dual Language Programme? 2) What are the challenges faced by teachers and students in Klang during the teaching and learning sessions after the implementation of the Dual Language Programme?

This section describes the results of data analysis based on the respondents' answers to the questionnaires and interviews that have been conducted.

\section{Students' Perceptions and Challenges}

Table 1: Students' Background Information

\begin{tabular}{|c|c|c|c|c|}
\hline No & Items & \multicolumn{2}{|c|}{ Response } & $\operatorname{Perc}(\%)$ \\
\hline \multirow[b]{2}{*}{1} & \multirow[b]{2}{*}{ Gender } & Male & 93 & 64 \\
\hline & & Female & 53 & 36 \\
\hline \multirow{4}{*}{2} & \multirow{4}{*}{ Race } & Malay & 58 & 40 \\
\hline & & Chinese & 20 & 14 \\
\hline & & Indian & 66 & 45 \\
\hline & & Others & 2 & 1 \\
\hline \multirow{5}{*}{3} & \multirow{5}{*}{ Language used at home } & English & 35 & 24 \\
\hline & & Malay & 55 & 38 \\
\hline & & Mandarin & 12 & 8 \\
\hline & & Tamil & 43 & 29 \\
\hline & & Others & 1 & 1 \\
\hline \multirow{5}{*}{4} & \multirow{5}{*}{ Second language used at home } & English & 103 & 70 \\
\hline & & Malay & 13 & 9 \\
\hline & & Mandarin & 6 & 4 \\
\hline & & Tamil & 20 & 14 \\
\hline & & Others & 4 & 3 \\
\hline
\end{tabular}

$n=146 \quad$ *Note: Perc: Percentage

The sample of this study consists of 146 students who study at SMK Tinggi Klang, SMK Meru, SMK Tengku Ampuan Rahimah and SMK Taman Klang Utama. There were 93 males and 53 females, made up of various races. Of the 146 samples collected, $40 \%$ (58) were Malays, 14\% (20) were Chinese, $45 \%$ (66) were Indians and 1\% (2) were others. There are 35 English speakers, 55 Malay speakers, 12 Mandarin speakers, 43 Tamil speakers and 1 Hokkien speaker. It could be seen that speakers feel more comfortable speaking in their mother tongue when communicating with others at home. However, students chose English as the second most widely used language in their homes. 
Table 2: Students' Perceptions of the Implementation of Dual Language Programme

\begin{tabular}{|c|c|c|c|c|c|}
\hline \multirow[b]{2}{*}{ No } & \multirow[b]{2}{*}{ Items } & \multicolumn{4}{|c|}{ Response } \\
\hline & & I agree & $\begin{array}{l}\text { Perc } \\
(\%)\end{array}$ & $\begin{array}{l}\text { I do not } \\
\text { agree }\end{array}$ & $\begin{array}{r}\text { Perc } \\
(\%)\end{array}$ \\
\hline 1 & $\begin{array}{l}\text { English is the international language of communication } \\
\text { and language of technology. }\end{array}$ & 146 & 100 & 0 & 0 \\
\hline 2 & Science / Mathematics should be taught in English. & 132 & 90.4 & 14 & 9.6 \\
\hline 3 & $\begin{array}{l}\text { The use of English for teaching and learning Science / } \\
\text { Mathematics can significantly improve students' English } \\
\text { proficiency. }\end{array}$ & 145 & 99.3 & 1 & 0.7 \\
\hline 4 & $\begin{array}{l}\text { The teaching and learning of Science / Mathematics in } \\
\text { English lead to confusion between words. }\end{array}$ & 74 & 50.7 & 72 & 49.3 \\
\hline 5 & $\begin{array}{l}\text { Teachers should use Malay as the medium of instruction } \\
\text { when teaching Science / Mathematics subjects, even } \\
\text { though the book is in English.. }\end{array}$ & 72 & 49.3 & 74 & 50.7 \\
\hline 6 & $\begin{array}{l}\text { I believe positively in the implementation of the Dual } \\
\text { Language Programme. }\end{array}$ & 144 & 98.6 & 2 & 1.4 \\
\hline 7 & $\begin{array}{l}\text { The teaching and learning of Science / Mathematics in } \\
\text { English has improved my exam results. }\end{array}$ & 96 & 65.8 & 50 & 34.2 \\
\hline
\end{tabular}

All students agreed that English is the global language of communication and the language of technology. Next, 132 students (90.4\%) strongly agreed that the teaching of Science / Mathematics should be conducted in English. Moreover, 145 respondents (99.3\%) chose that students' English proficiency can be significantly improved through the use of English for the teaching and learning of Science / Mathematics. Furthermore, almost half of the students $(50.7 \%)$ claimed that the teaching and learning of Science / Mathematics in English caused confusion between terms. Moreover, 74 students $(50.7 \%)$ agreed that teachers should not use Malay as the medium of instruction when teaching Science / Mathematics subjects. The implementation of the Dual Language Programme is not an easy task for the ministry and schools, but a total of 144 students $(98.6 \%)$ were positive about the implementation of this programme. Finally, only 96 students (65.8\%) chose that teaching and learning Science / Mathematics in English had improved their examination results.

Table 3: Challenges Faced by Students during the Teaching and Learning Session after the Implementation of the Dual Language Programme

\begin{tabular}{|c|c|c|c|c|c|}
\hline \multirow[b]{2}{*}{ No } & \multirow[b]{2}{*}{ Items } & \multicolumn{4}{|c|}{ Response } \\
\hline & & Yes & $\begin{array}{l}\text { Perc } \\
(\%)\end{array}$ & No & $\begin{array}{l}\text { Perc } \\
(\%)\end{array}$ \\
\hline 1 & $\begin{array}{l}\text { I have difficulty learning Science / Mathematics in } \\
\text { English. }\end{array}$ & 71 & 48.6 & 75 & 51.4 \\
\hline 2 & $\begin{array}{l}\text { List of challenges faced by students during teaching and } \\
\text { learning sessions. }\end{array}$ & \multicolumn{4}{|c|}{ Refer to Table 4} \\
\hline 3 & $\begin{array}{l}\text { I often use code-switching (a mixture of English and } \\
\text { Malay) in my answers when teachers ask questions. }\end{array}$ & 45 & 30.8 & 101 & 69.2 \\
\hline 4 & $\begin{array}{l}\text { I usually ask my teacher to explain in Malay instead of } \\
\text { English. }\end{array}$ & 68 & 46.6 & 78 & 53.4 \\
\hline
\end{tabular}




\begin{tabular}{|c|c|c|c|c|c|}
\hline & & $\begin{array}{l}\text { English } \\
\text { Language }\end{array}$ & $\begin{array}{l}\text { Perc } \\
(\%)\end{array}$ & $\begin{array}{c}\text { Malay } \\
\text { Language }\end{array}$ & $\begin{array}{l}\text { Perc } \\
(\%)\end{array}$ \\
\hline 5 & $\begin{array}{l}\text { I prefer to use the } \\
\text { Science / Mathematics. }\end{array}$ & 116 & 79.5 & 30 & 20.5 \\
\hline 6 & List of answers to why students prefer that language. & \multicolumn{4}{|c|}{ Refer to Table 5 and Table 6} \\
\hline
\end{tabular}

Table 4: List of challenges that DLP students have faced

\begin{tabular}{|l|l|}
\hline Student 1 & $\begin{array}{l}\text { "I'm having a problem with grammar and vocabulary. Sometimes, I don't understand } \\
\text { the questions at all." }\end{array}$ \\
\hline Student 2 & "There are terms/words that are very hard to understand and remember." \\
\hline Student 3 & $\begin{array}{l}\text { "Sometimes, I will translate Malay words into English during the exams. I want to } \\
\text { learn Mathematics and Science in English, but sometimes I give up because it's hard } \\
\text { to understand." }\end{array}$ \\
\hline Student 4 & "It's very difficult for me to communicate in class." \\
\hline Student 5 & "I will get confused by some of the words taught in class." \\
\hline
\end{tabular}

The findings of the study showed that 71 students (48.6\%) faced difficulties while learning Science and Mathematics in English. Code-switching occurs when a person uses more than one language in a sentence. Only 45 students $(30.8 \%)$ stated that they mixed English and Malay in the discourse while answering questions. Furthermore, 68 students $(46.6 \%)$ claimed that they would ask the teacher to explain in Malay instead of English. Finally, 116 out of 146 students (79.5\%) stated that they preferred to use English while learning Science / Mathematics compared to 30 students (20.5\%) who chose to use Malay while learning Science / Mathematics.

Table 5: List of answers to why students prefer the English language

\begin{tabular}{|l|l|}
\hline Student 1 & "It will be easier for us at university later because the lectures will be in English." \\
\hline Student 2 & $\begin{array}{l}\text { "The English language is interesting to learn, and I can understand it easily } \\
\text { because I always speak English at home." }\end{array}$ \\
\hline Student 3 & "I wanted to improve my English speaking skills." \\
\hline Student 4 & $\begin{array}{l}\text { "It is a universal language. So, when you travel around the world, you have to use } \\
\text { the English language, not Malay." }\end{array}$ \\
\hline
\end{tabular}

Table 6: List of answers to why students prefer the Malay language

\begin{tabular}{|l|l|}
\hline Student 1 & "I speak Malay every day." \\
\hline Student 2 & "It's easy to understand the meaning of a word. " \\
\hline Student 3 & $\begin{array}{l}\text { "This language has become a part of my life in understanding something or } \\
\text { communicating." }\end{array}$ \\
\hline
\end{tabular}




\section{Teachers' Perceptions and Challenges}

Table 7: Teachers' Background Information

\begin{tabular}{ccccc}
\hline No & Items & \multicolumn{2}{c}{ Response } & Perc (\%) \\
\hline \multirow{2}{*}{1} & \multirow{2}{*}{ Gender } & Male & 2 & 25 \\
\cline { 3 - 5 } & \multirow{2}{*}{2} & Female & 6 & 75 \\
\hline \multirow{2}{*}{ Subject being taught } & Science & 4 & 50 \\
\cline { 3 - 4 } & & Mathematics & 4 & 50 \\
\hline
\end{tabular}

n=8 *Note: Perc: Percentage

Table 7 shows the background information of the teachers. There were 2 male teachers and 6 female teachers who participated in this study. They are from SMK Tinggi Klang, SMK Meru, SMK Tengku Ampuan Rahimah and SMK Taman Klang Utama, where 4 teachers teach Science, and another 4 teachers teach Mathematics.

Table 8: Teachers' Perceptions of the Implementation of Dual Language Programme

\begin{tabular}{|c|c|c|c|c|c|}
\hline \multirow[b]{2}{*}{ No } & \multirow[b]{2}{*}{ Items } & \multicolumn{4}{|c|}{ Response } \\
\hline & & I agree & $\begin{array}{c}\text { Perc } \\
(\%)\end{array}$ & $\begin{array}{l}\text { I do not } \\
\text { agree }\end{array}$ & $\begin{aligned} \text { Perc } \\
(\%)\end{aligned}$ \\
\hline 1 & $\begin{array}{l}\text { English is the international language of communication } \\
\text { and language of technology. }\end{array}$ & 8 & 100 & 0 & 0 \\
\hline 2 & Science / Mathematics should be taught in English. & 7 & 87.5 & 1 & 12.5 \\
\hline 3 & $\begin{array}{l}\text { The use of English for teaching and learning Science / } \\
\text { Mathematics can significantly improve my students' } \\
\text { English proficiency. }\end{array}$ & 6 & 75 & 2 & 25 \\
\hline 4 & $\begin{array}{l}\text { The teaching and learning of Science / Mathematics in } \\
\text { English lead to confusion between words. }\end{array}$ & 5 & 62.5 & 3 & 37.5 \\
\hline 5 & $\begin{array}{l}\text { I often use Malay as the medium of instruction for some } \\
\text { students when teaching Science / Mathematics subjects, } \\
\text { even though the book is in English. }\end{array}$ & 5 & 62.5 & 3 & 37.5 \\
\hline 6 & $\begin{array}{l}\text { I believe positively in the implementation of the Dual } \\
\text { Language Programme. }\end{array}$ & 7 & 87.5 & 1 & 12.5 \\
\hline 7 & $\begin{array}{l}\text { The teaching and learning of Science / Mathematics in } \\
\text { English has improved my students' exam results. }\end{array}$ & 6 & 75 & 2 & 25 \\
\hline
\end{tabular}

All teachers agreed that English is an international language. 7 teachers (87.5\%) agreed that they should teach Science and Mathematics in English. Furthermore, 6 teachers (75\%) agreed that teaching Science and Mathematics using English can improve their student's English proficiency. However, 5 teachers (62.5\%) claimed that the teaching and learning of Science / Mathematics in English caused confusion between words. Furthermore, they also claimed to use Malay as the medium of instruction even though the book was in English. Most teachers believe positively in the objectives of the implementation of the Dual Language Programme, where 6 teachers (75\%) stated that there was an improvement in students' performances in the examinations after the Dual Language Programme was introduced. 
Table 9: Challenges Faced by Teachers during the Teaching and Learning Session after the Implementation of the Dual Language Programme

\begin{tabular}{|c|c|c|c|c|c|}
\hline \multirow[b]{2}{*}{ No } & \multirow[b]{2}{*}{ Items } & \multicolumn{4}{|c|}{ Response } \\
\hline & & I agree & $\begin{array}{l}\text { Perc } \\
(\%)\end{array}$ & $\begin{array}{l}\text { I do not } \\
\text { agree }\end{array}$ & $\begin{array}{c}\text { Perc } \\
(\%)\end{array}$ \\
\hline 1 & $\begin{array}{l}\text { I have difficulty teaching Science / Mathematics in } \\
\text { English. }\end{array}$ & 6 & 75 & 2 & 25 \\
\hline 2 & $\begin{array}{l}\text { List of challenges faced by teachers during teaching and } \\
\text { learning sessions. }\end{array}$ & \multicolumn{4}{|c|}{ Refer to Table 10} \\
\hline 3 & $\begin{array}{l}\text { I often use code-switching (a mixture of English and } \\
\text { Malay) when teaching and answering students' questions. }\end{array}$ & 8 & 100 & 0 & 0 \\
\hline \multirow[t]{2}{*}{4} & $\begin{array}{l}\text { My students usually ask me to explain in Malay instead of } \\
\text { English. }\end{array}$ & 6 & 75 & 2 & 25 \\
\hline & & $\begin{array}{c}\text { English } \\
\text { Language }\end{array}$ & $\begin{array}{c}\text { Perc } \\
(\%)\end{array}$ & Bilingual & $\begin{array}{r}\text { Perc } \\
(\%)\end{array}$ \\
\hline 5 & $\begin{array}{l}\text { I prefer to use the } \\
\text { Science / Mathematics. }\end{array}$ & 4 & 50 & 4 & 50 \\
\hline 6 & List of answers to why teachers prefer that language. & & fer to Ta & le 11 and 12 & \\
\hline
\end{tabular}

The findings of the study showed that 6 teachers $(75 \%)$ claimed that they faced difficulties while teaching Science and Mathematics in English. All teachers stated that they used code-switching when teaching and answering students' questions. Besides, 6 teachers (75\%) claimed that their students usually asked them to explain in Malay instead of English. Furthermore, 4 teachers (50\%) preferred English, while another 4 $(50 \%)$ preferred Bilingual to teach these two subjects.

Table 10: Challenges faced by teachers during teaching and learning sessions

\begin{tabular}{|l|l|}
\hline $\begin{array}{l}\text { Science } \\
\text { Teacher }\end{array}$ & $\begin{array}{l}\text { "My students are not good at English, so I had to introduce new terms for } 15 \text { minutes } \\
\text { before each class started. It is difficult for them to learn Science and Mathematics in } \\
\text { English because Science and Mathematics were taught in Bahasa Malaysia during } \\
\text { primary school." }\end{array}$ \\
\hline $\begin{array}{l}\text { Mathematics } \\
\text { Teacher }\end{array}$ & $\begin{array}{l}\text { "Some of my students don't understand English. So, I have to translate my instructions } \\
\text { and explanation into Malay for them. Translation takes time." }\end{array}$ \\
\hline $\begin{array}{l}\text { Science } \\
\text { Teacher }\end{array}$ & $\begin{array}{l}\text { "I teach Science in English and Malay due to the shortage of DLP teachers. So, } \\
\text { confusion between words often happens." }\end{array}$ \\
\hline
\end{tabular}


Table 11: Teacher's answer why prefers the English language

\begin{tabular}{|l|l|}
\hline $\begin{array}{l}\text { Mathematics } \\
\text { Teacher }\end{array}$ & "Since English is an international language, I think Science and Mathematics should be \\
taught in English. It also exposes students to new English words. "
\end{tabular}

Table 12: Teacher's answer why prefers bilingual

Mathematics

Teacher

"Students' backgrounds vary according to the language used at home."

\section{Interviews}

Interviews are one of the most imperative pieces of evidence for subjective research. The behaviours, feelings and ways people interpret the world around them cannot be explained through observation alone. Therefore, interviews were conducted with 8 teachers from 4 secondary schools based in Klang to discover their challenges and perceptions after the implementation of the Dual Language Programme.

\begin{tabular}{|c|c|}
\hline Interview Questions & Teachers' Answers \\
\hline \multirow{3}{*}{$\begin{array}{l}\text { 1. What are the common problems } \\
\text { you face every day? }\end{array}$} & $\begin{array}{r}\text { "Students can't understand my explanation in English." } \\
\text { (Mathematics Teacher) }\end{array}$ \\
\hline & $\begin{array}{l}\text { "It is difficult to teach in two languages. I am fine with English, } \\
\text { but it takes a bit of time for me to recall the Science terms in } \\
\text { Malay to teach Science in Malay language classes." } \\
\text { (Science Teacher) }\end{array}$ \\
\hline & $\begin{array}{l}\text { "It takes too much time to prepare teaching materials for both } \\
\text { languages." } \\
\text { (Science Teacher) }\end{array}$ \\
\hline \multirow[t]{2}{*}{$\begin{array}{l}\text { 2. How do you deal with students } \\
\text { with low English proficiency? }\end{array}$} & $\begin{array}{l}\text { "I will explain in Malay to students who do not understand my } \\
\text { explanation during the teaching and learning session." } \\
\text { (Science Teacher) }\end{array}$ \\
\hline & $\begin{array}{r}\text { "Sometimes, I will prepare some English exercises for students." } \\
\text { (Science Teacher) }\end{array}$ \\
\hline \multirow{3}{*}{$\begin{array}{l}\text { 3. Any other suggestions or opinions } \\
\text { on the education system? }\end{array}$} & $\begin{array}{l}\text { "The Ministry of Education must ensure that our education policy } \\
\text { is focused on the future and remains unchanged." } \\
\text { (Mathematics Teacher) }\end{array}$ \\
\hline & $\begin{array}{l}\text { "I prefer PPSMI because I can use both Malay and English to } \\
\text { teach Mathematics where students will understand it more } \\
\text { easily." } \\
\text { (Mathematics Teacher) }\end{array}$ \\
\hline & $\begin{array}{l}\text { "DLP is a barrier for students. Students with poor English- } \\
\text { speaking skills will find it difficult to communicate with students } \\
\text { who have good English-speaking skills." } \\
\text { (Science Teacher) }\end{array}$ \\
\hline
\end{tabular}




\section{DISCUSSIONS}

English is a widely used language, especially in fields of science and technology. According to Drubin and Kellogg (2012), English became the language of science. English is one of the languages used in most activities related to science and technology (Foyewa, 2015). Furthermore, science and technology are the main factors that drive the development of a country (Anaeto et al., 2016). In addition, mathematics is also one of the pieces of knowledge closely associated with science in many aspects (The Science Checklist Applied: Mathematics, n.d.). Recognising the importance of English, the Malaysian Cabinet decided that Science and Mathematics be taught in English. If the ministry decides to teach these subjects in Malay, there will be a huge impact on students and national education system, both in the short and long term. Tun Dr Mahathir Mohamad stated that the national education policy would not be affected if schools used English to teach Mathematics and Science. According to him, Science and Mathematics are not like other subjects which can be learned in Bahasa Malaysia (The Star, 13 June 2015).

Most teachers and students in Klang agree that the teaching and learning of Science and Mathematics in English can improve a person's level of English proficiency. These results can be ascertained through a study conducted by Nora et al. (2011), where the study found that teaching Science and Mathematics in English can improve a student's English proficiency. Although students faced some challenges, there was a slight improvement in their exam results based on the findings of the study. Nevertheless, this study clearly shows that most students have problems learning Science and Mathematics in English. Most of them do not understand what the teacher is teaching and the content of the book. As students are unfamiliar with English terms, they find it difficult to understand and remember new words/terms. Also, they are confused with words that sound the same but are spelt differently.

Teachers continue to use Malay as the medium of instruction and translation since some students are weak in understanding their explanations and lessons in English. So, these students expect their teachers to explain in Malay since it is easy to understand. Razianna (2005), in her study, stated that translation has helped her students understand English texts (as cited in Normazidah, Yew Lie \& Hazita, 2012, pp.38). According to Charis Ding, co-founder of the My Readers literacy program, a number of secondary students still fail to master English. (Malaysiakini, 25 May 2017). Previously, this issue was highlighted in a study conducted by Hiew (2012). Students need to accept the fact that they need to master English as much as possible. Although teachers continue to use Malay as the MOI, it will not yield satisfactory results. However, students still prefer Malay since they learn most of the subjects in Malay during their primary school years.

Next, according to a Science teacher, even if they are proficient in more than one language, it is not as easy for them to switch to another language at a glance. Although the content of Science subject is the same, the terminology differs in terms of language. Therefore, the Ministry of Education should look into this matter immediately by increasing the number of DLP teachers so that each teacher teaches Science/Mathematics in one language only. Besides, the preparation of more than one teaching material will burden them. It takes more time, as they have to prepare by themselves and, on top of that, teachers have to ensure it is in line with the students' level of learning. For instance, the Science teacher in Klang took the initiative by providing some English exercises for students and introducing new English terms before each class started. Indeed, it takes some time to prepare it.

It was found that most teachers were not given DLP training courses; as a result, teachers are not prepared for such changes. Nadiah \& Melor (2018), in their study, stated that teachers are less confident in handling DLP classes due to lack of guidance. Therefore, MOE should provide more intensive training to teachers to increase their confidence levels. Gunal \& Demir (2012) stated that for every new curriculum being introduced, teachers should be provided with complete guidelines so that the objectives of the curriculum can be achieved. Besides, most schools are not equipped with adequate materials and resources to conduct DLP classes. Hence, the ministry should provide adequate teaching and learning materials and resources so that teachers can teach effectively. 
Although teachers have been teaching in schools for many years and have attended many conferences/ seminars/ lectures related to it, they will still face challenges if policies constantly change every time the country's leadership changes. Teachers need some time to understand the policy, practice and prepare themselves with new teaching concepts. Furthermore, changes in education policy will affect students (Norhisham, Norazilawati \& Noraini, 2018). Thus, the ministry should stick to a policy that prepares students for the future. However, there are also teachers who prefer PPSMI over DLP. Teachers believe that PPSMI gives them and their students an advantage as it allows them to use a mixture of Bahasa Malaysia and English.

In addition, some teachers label DLP as a programme that prevents students from different classes from communicating with each other. Some students learn Science/Mathematics in English, while others learn those subjects in Malay. Therefore, students from each class will be proficient in only one language. As a result, students learning in Malay may have difficulty communicating with students learning in English due to language differences.

The Ministry of Education is recommended introducing Diagnostic Assessment to students taking DLP classes (in all schools) to improve DLP. Form 1 students who have no experience in learning Science and Mathematics in English face problems during the learning sessions. Therefore, Diagnostic Assessment will help resolve the issue. It is not an idea to divide the class into two groups that have mastered English and groups that have not mastered English but to help teachers identify students' proficiency levels. If students do not reach the minimum level, teachers should guide them and ensure no one is left behind.

Finally, English proficiency among teachers is important to facilitate teaching and learning. Professor Dr. Saedah Siraj from Universiti Pendidikan Sultan Idris has voiced her concern over the confusion among students during teaching and learning sessions that could occur due to lack of language proficiency. She also pointed out that this problem often arises in secondary schools (New Straits Times, 10 March 2019). Therefore, to resolve this issue, the schools are advised to organise English courses every month so that teachers can conduct teaching in English smoothly and minimise the use of codemixing and code-switching to master English. Moreover, teachers should encourage students to speak or ask questions in English. If students practice speaking English in the classroom, they can improve their English language skills (Abda, 2017).

\section{CONCLUSION}

Although students' English proficiency is still at an unfavourable level, most students accept the challenge of learning Science and Mathematics in English. It can be seen that most students are aware of the importance of English. Therefore, teachers need to apply effective teaching strategies so that students will also master the English language. From the researcher's point of view, DLP implementation has pros and cons. The advantage is that it aims to enhance students' English proficiency. In contrast, the disadvantage is that it gives students the option to choose either Malay or English as the MOI in the learning of Science and Mathematics. It seems that DLP does not encourage students to learn Science and Mathematics in English.

The findings of this study also show the extent to which students and teachers are prepared to face challenges in today's modern world. Therefore, the Ministry of Education should work with the schools and analyse the challenges both teachers and students face to make DLP a success. Moreover, it is undeniable that it requires cooperation from parents as well as the community. This research does not represent all students and teachers in Malaysia. Thus, this study can be further intensified by using a large sample of studies involving students and teachers from all states in Malaysia, including urban and rural areas. 


\section{REFERENCES}

Abda, K. (2017). Assessing the Factors that Affect Teaching Speaking Skills: The Case of Robe Teachers' College, English Department Second Year Students. International Journal of Humanities \& Social Science Studies, 3(5), 285-299.

Anaeto, F. C., Asiabaka, C. C., Ani, A. O., Nnadi, F. N., Ugwoke, F. O., Asiabaka, I. P., Anaeto, C. A., \& Ihekeronye, N. (2016). The Roles of Science and Technology in National Development. Direct Research Journal of Social Science and Educational Studies, 3(3), 38-43.

Ashairi Suliman, Mohamed Yusoff Mohd Nor \& Melor Md Yunus. (2017). Dual-Language Programme in Malaysian Secondary Schools: Are You Ready? Paper presented at the Seminar Serantau. Malaysia: Universiti Kebangsaan Malaysia, September.

Carolyn, S. (n.d.). The Importance of Mother Tongue Language in Education. Consilium Education. Retrieved from https://consiliumeducation.com/itm/2017/08/20/mother-tongue-learning/

Drubin, D. G., \& Kellogg, D.R. (2012). English as Universal Language of Science: Opportunities and Challenges. Molecular Biology of the Cell, 23(8), 1399. doi.org/10.1091/mbc.e12-02-0108

Foyewa, R. A. (2015). English: The International Language of Science and Technology. International Journal of English Language and Linguistics Research, 3(5), 34-41.

Free Malaysia Today. (2019, 11 April). Scuffle Erupts Between PH Supporters and NGO in Rantau. Retrieved from https://www.freemalaysiatoday.com/category/nation/2019/04/11/war-of-words-erupts-between-phsupporters-and-ngo-in-rantau/

Gunal, O.D., \& Demir, C.E. (2012). Implementation of the New Eighth Grade English Language Curriculum from the Perspectives of Teachers and Students. Procedia Social and Behavioral Sciences, 47, 1002-1006. doi: 10.1016/j.sbspro.2012.06.769

Izquierdo, I. (2017). Let's Talk: Increasing Communication in the Dual-Immersion Setting. Capstone Projects and Master's Theses. 220. Retrieved from https://digitalcommons.csumb.edu/caps_thes_all/220

Jesica Gambong Unting \& Hamidah Yamat. (2017). Dual Language Programme (DLP): Teachers' Voice. Proceedings of the 73rd ISERD International Conference, Bali, Indonesia, 13-14 May (pp. 20-24).

Malay Mail. (2019, 6 February). PAS MP Tells Putrajaya To Spell Out Dual-Language Programme. Retrieved from https://www.malaymail.com/news/malaysia/2019/02/06/pas-mp-tells-putrajaya-to-spell-out-dual-languageprogramme/1720189

Malaysiakini. (2017, 25 May). Some Secondary School Students Still Illiterate in English. Retrieved from https://www.malaysiakini.com/news/383431

Melor Md Yunus, Nur Ainil Sulaiman \& Mohammed Amin Embi. (2013). Malaysian Gifted Students' Use of English Language Learning Strategies. English Language Teaching, 6(4), 97-109. doi.org/10.5539/elt.v6n4p97

Melor Md Yunus \& Saiful Islam Ahmad Sukri. (2017). The Use of English in Teaching Mathematics and Science: The PPSMI Policy vis-à-vis The DLP. Advances in Language and Literary Studies, 8(1), 133-142. doi:10.7575/aiac.alls.v.8n.1p.133

Nadiah Has Bullah \& Melor Md Yunus. (2018). Dual Language Programme: Parent's Perception. Proceedings of the 11th International Conference on Language, Education, and Innovation 2018, Singapore, 11-12 August (pp. 86-96).

Nadiah Has Bullah \& Melor Md Yunus. (2018). Teachers' Perception on the Implementation of Dual Language Programme (DLP) in Urban Schools, Asian Social Science, 15(1), 24-31. doi:10.5539/ass.v15n1p24

Nair, M. (2019, 10 August). Politicians Are Failing Our Education System. Free Malaysia Today. Retrieved from https://www.freemalaysiatoday.com/category/opinion/2019/08/10/politicians-are-failing-our-educationsystem/

New Straits Times. (2019, 10 March). MOE Urged to Intensify Training to Improve Teachers' English Proficiency. Retrieved from https://www.nst.com.my/news/nation/2019/03/467780/moe-urged-intensify-trainingimprove-teachers-english-proficiency 
Nora Muda, Wan Rosmanira Ismail, Faridatulazna Ahmad Shahabudin, Humaida Banu Samsudin, Nur Riza Mohd Suradi, Noriza Majid, Rokiah @ Rozita Ahmad, Azmin Sham Rambely, Nur Jumaadzan Zaleha Mamat, Ummul Khair Salma Din, Saiful Hafizah Hj Jaaman, Nasruddin Hassan, Roslinda Mohd Nazar, Zainol Mustafa, Zalina Mohd Ali, Zaidi Isa, Hamizun Ismail, Wan Zawiah Wan Zin, Marina Zahari, Norkisme ZainalAbidin, Abdul Razak Salleh, Abdul Malek Zakaria, Maslina Darus, Abdul GhafurAhmad, \& Najib Mahmood Rafee. (2011). Teaching Science and Mathematics in English Steering Mastery in English Language amongst Sciences Students in UKM. Procedia Social and Behavioral Sciences, 59, 670 - 677. doi: $10.1016 /$ j.sbspro.2012.09.329

Norhisham Shamsudin, Norazilawati Abdullah \& Noraini Mohamed Noh. (2018). Kesediaan Guru Sains Sekolah Rendah Terhadap Pelaksanaan Dual Language Programme (DLP) [The Readiness of Primary School Science Teachers towards the Implementation of Dual Language Program (DLP)]. Jurnal Pendidikan Sains \& Matematik Malaysia, 8(1), 34-45. doi.org/10.37134/jpsmm.vol8.1.3.2018

Normazidah Che Musa, Yew Lie, K., \& Hazita Azman. (2012). Exploring English Language Learning and Teaching in Malaysia. GEMA Online Journal of Language Studies, 12(1), 35-51.

Nurfaradilla Mohamad Nasri, Sarah Mohamad Yunus \& Sharifah Intan Sharina Syed Abdullah. (2018). Exploring Dual Language Program (DLP) Science Teachers' Perceptions and Experiences of Curriculum Change. International Journal of Academic Research in Progressive Education and Development, 7(4), 303-318.

Official Portal for Ministry of Education Malaysia. (2015). Surat Siaran Kementerian Pendidikan Malaysia Bilangan 18 Tahun 2015 - Pelaksanaan Rintis Program Dwibahasa Atau Dual Language Programme (DLP) Di Sekolah Pada Tahun 2016 [Ministry of Education Malaysia Number 18 Year 2015 Press Letter - Implementation of the Dual Language Program (DLP) at School in 2016].

Sinar Harian. (2019, 12 March). Tiada Keperluan Sains, Matematik dalam Bahasa Inggeris. [No Requirement for Science, Mathematics in English]. Retrieved from https://www.sinarharian.com.my/article/17693/BERITA/Nasional/Tiada-keperluan-Sains-Matematikdalam-Bahasa-Inggeris

The Star. (2015, 13 June). Teach Maths and Science in English, says Mahathir. Retrieved from https://www.thestar.com.my/news/nation/2015/06/13/teach-maths-and-science-in- english-says-mahathir

The Star. (2018, 5 January). NUTP Urges Teachers to Fact-Check DLP. Retrieved from https://www.thestar.com.my/news/nation/2018/01/05/nutp-urges-teachers-to-factcheck-dlp

The Sun Daily. (2016, 5 October). Dong Zong, Chinese Educationist Groups Hand Over DLP Objection Memorandum. Retrieved from https://www.thesundaily.my/archive/1993033-ESARCH399215

The Science Checklist Applied: Mathematics. (n.d.). Understanding Science. Retrieved from https://undsci.berkeley.edu/article/mathematics\#

Hiew, W. (2012). English Language Teaching and Learning Issues in Malaysia: Learners' Perceptions via Facebook Dialogue Journal. Journal of Arts, Science \& Commerce, 3(1), 11-19. 